\title{
ANALISIS SIMULTANITAS KEBIJAKAN HUTANG DAN KEBIJAKAN MATURITAS HUTANG SERTA FAKTOR-FAKTOR YANG MEMPENGARUHINYA
}

\author{
Sunarsih \\ UIN Sunan Kalijaga
}

\begin{abstract}
This study is aimed to test the relationship between leverage and debt maturity policies, and to reveal the factors influencing on simultaneity analysis of leverage and debt maturity policies on Indonesia manufacture industry. This specific study took 130 firms, which were listed in Jakarta Stock Exchange from 1994 until 1998, as its sample. Data are gathered through pooling data. The endogenous variables that are used in this study are: leverage and debt maturity. While the exogenous variable are: (1) invistment opportunity set, (2) firm size, (3) signaling effect, (4) non debt-tax shiled and (5) asset maturity. Using two-stage least square (2SLS) as method analysis, the result of the analysis shows that firm size and non debt-tax shield have significant influence on leverage policy, but inconsistent with the hypothesis. While firm size, signaling effect, and asset maturity have significant ifluence on debt maturity policy. This study revealed the complement relationship between leverage and debt maturity. It mean that both policies have simultaneous relationship positively.
\end{abstract}

Keyword: Simultaneity, leverage, debt maturity, invistment opportunity set, firm size, signaling effect, non debt-tax shiled, and asset maturity.

\section{PENDAHULUAN}

Perusahaan yang telah go public dalam perkembangannya masih memerlukan tambahan modal guna membiayai kegiatan usahannya atau untuk melakukan ekspansi. Tambahan modal tersebut dapat berasal dari berbagai sumber dan bentuk yang berbeda-beda. Namun semua sumber modal yang ada dapat diklasifikasikan kedalam dua tipe dasar, yaitu hutang dan equity (Brigham, et.al.,1999). Dimana perusahaan harus menentukan sumber pendanaan yang akan digunakan. Selain itu perusahaan juga menghadapi berbagai pilihan kebijakan financial dalam menentukan kebijakan struktur modalnya (Barclay et.al., 1995; Barclay, et.al.,2001).

Menurut Barclay dan Smith (1995) ketika perusahaan memilih hutang sebagai sumber pendanaan maka, perusahaan juga harus mempertimbangkan kebijakan-kebijakan financial yang lain, misalnya: debt maturity, priority, apakah menggunakan public debt ataukah private debt, dan lain-lain. Dengan demikian dapat dikatakan bahwa persoalan-persoalan yang dihadapi oleh perusahaan sering terjadi secara bersama-sama (Barclay, et. al., 2001).

Oleh karena itu, ketika perusahaan memilih hutang sebagai sumber pendanaan, maka perusahaan juga perlu mempertimbangkan maturitas 
hutang (debt maturity) tersebut. Hal ini dikarenakan pemilihan maturitas hutang (debt maturity) akan mempengaruhi nilai perusahaan (Megginson, 1997). Ini berarti bahwa penentuan kebijakan hutang dan kebijakan maturitas hutang harus dipertimbangkan secara bersama-sama (simultan). Hal ini sesuai dengan apa yang disampaikan oleh Barclay dan Smith (1995) yang menyatakan bahwa apabila perusahaan memilih hutang sebagai sumber financial perusahaannya, maka perusahaan juga dihadapkan pada keputusan untuk menentukan pilihan tentang debt maturity secara bersama-sama (simultaneously).

Berbeda dengan penelitian yang telah dilakukan oleh Barclay dan Smith (1995) serta Stohs dan Mauer (1996) yang memandang bahwa antara kebijakan leverage dan kebijakan debt maturity adalah independen (tidak simultan), Barclay, et.al. (2001) mencoba untuk menguji tentang simultanitas antara kebijakan leverage dengan debt maturity. Dalam penelitian tersebut, leverage dan debt maturity digunakan sebagai variabel endogen maupun sebagai variabel eksogen dari kebijakan yang berbeda.

Berdasarkan kerangka pemikiran Barclay, et.al. (2001), maka penelitian ini akan menguji simultanitas antara kebijakan hutang (leverage) dengan kebijakan maturitas hutang (debt maturity), dengan tujuan untuk mengetahui hubungan kedua kebijakan tersebut serta faktor-faktor yang mempengaruhi keduanya, pada perusahaan manufaktur di Indonesia, dengan periode waktu penelitian tahun 1994 sampai 1998.

Metode analisis yang akan digunakan untuk menguji simultanitas antara kebijakan hutang dan kebijakan maturitas hutang (debt maturity) dalam penelitian ini adalah analisis simultan two-stage least square (2SLS).

Dalam analisis simultan 2SLS ini, variabel eksogen yang akan digunakan adalah sebagai berikut: (1) investment opportunity set, (2) firm size, dan (3) efek signaling. Dua variabel lain akan ditambahkan sebagai syarat identifikasi persamaan simultan 2SLS, yaitu variabel non debt-tax shield yang akan ditambahkan pada persamaan leverage dan variabel asset maturity yang ditambahkan pada persamaan debt maturity.

Kerangka dari penelitian ini adalah sebagai berikut: bagian pertama akan menjelaskan tentang latar belakang penelitian, bagian kedua akan menjelaskan tinjauan literature dan pengembangan hipotesis, bagian ketiga akan membicarakan tentang metode penelitian, bagian empat akan menjelaskan hasil penelitian dan bagian lima akan membahas tentang simpulan, keterbatasan, dan implikasi penelitian mendatang. 


\section{TINJAUAN LITERATUR DAN PENGEMBANGAN HIPOTESIS}

\section{Investment Opportunity Set}

Myers (1977) mengemukakan konsep investment opportunity set (IOS) yang menyatakan bahwa perusahaan merupakan kombinasi antara assets in place (tangible assets) dan investment opportunities (intangible assets). Kombinasi keduanya menurut Myers (1977) serta Smith dan Watts (1992) dapat mempengaruhi struktur modal perusahaan dan nilai perusahaan. Dimana nilai perusahaan di masa depan akan ditentukan oleh ketetapan manajer (managerial discretion) saat ini, apakah akan memanfaatkan investment opportunity yang ada atau tidak, untuk meningkatkan pertumbuhan perusahaan.

Lebih lanjut Myers (1977) berargumen bahwa kesempatan investasi yang dimiliki oleh perusahaan dimasa depan adalah seperti sebuah opsi. Nilai opsi ini sangat tergantung pada kemungkinan perusahaan untuk melakukan investasi tersebut secara maksimal. Menurut Jensen (1986) perusahaan dengan investment opportunity yang tinggi, biasanya memiliki tingkat pertumbuhan yang tinggi (high growth), aktif melakukan investasi, memiliki free cash flow yang rendah dan assets in place yang kecil. Pada perusahaan yang memiliki investment opportunity yang tinggi dan memiliki tingkat pertumbuhan yang tinggi, masih aktif melakukan kegiatan investasi, maka cash flow yang diperoleh masih akan tetap memberikan keuntungan bila diinvestasikan kembali ke dalam perusahaan. Pada keadaan demikian perusahaan akan berusaha melaksanakan kesempatan yang ada untuk bertumbuh. Dengan demikian perusahaan pada umumnya memiliki free cash flow yang rendah, dan berpotensi memiliki underinvestment problem.

Underinvestment problem akan muncul apabila perusahaan menghadapi kesempatan berinvestasi pada proyek dengan NPV positif, yang mensyaratkan menggunakan dana yang besar. Dalam keadaan free cash flow yang rendah dan assets in place yang kecil, untuk memenuhi dana guna meneruskan proyek yang ada, maka perusahaan cenderung mengambil hutang. Hal ini akan memungkinkan terjadinya konflik antara shareholder dengan bondholder. Dari sisi shareholder keuntungan harus dibagi sebagai deviden, sedangkan dari sisi bondholder keuntungan sebaiknya digunakan untuk melunasi hutang. Dalam beberapa kasus bondholder memperoleh keuntungan yang cukup, sedangkan shareholder tidak memperoleh keuntungan yang normal dari proyek dengan NPV positif yang dilaksanakan tersebut. Hal ini menunjukkan bahwa penggunaan hutang pada perusahaan yang memiliki investment opportunity yang tinggi adalah mahal. Sehingga perusahaan pada keadaan seperti ini akan memilih untuk meninggalkan proyek dengan NPV positif dan kehilangan kesempatan untuk tumbuh. 
Untuk meneruskan proyek-proyek dengan NPV positif, sehingga dapat mempertahankan pertumbuhannya, maka perusahaan dengan investment opportunity yang tinggi sebaiknya menggunakan hutang dalam jumlah yang kecil, atau menggunakan dana internal yang dimiliki perusahaan sebagai alternatif pendanaan. Dengan demikian diprediksikan bahwa hubungan antara leverage dengan investment opportunity (growth options) adalah negatif.

Berbagai studi empiris untuk membuktikan adanya hubungan yang negatif antara investment opportunity dengan tingkat leverage telah dilakukan, diantaranya: Long, et.al. (1995), Gaver dan Gaver (1993), serta Rajan dan Zingales (1995).

Sedangkan pada perusahaan dengan investment opportunity yang kecil, yaitu perusahaan-perusahaan yang berada pada tahap mature, tingkat pertumbuhan yang lambat (slow growth), memiliki assets in place dan free cash flow yang tinggi, dimungkinkan menghadapi overinvestment problem. Jensen (1986) berpendapat bahwa penyebab overinvestment problem pada perusahaan yang slow growth adalah kelebihan modal (free cash flow). Hal ini dikarenakan kelebihan modal yang terjadi kurang menguntungkan bila diinvestasikan kembali ke dalam perusahaan, sehingga manajer cenderung menginvestasikan kelebihan modal tersebut pada proyek-proyek lain. Pada keadaan seperti ini terjadi konflik antara shareholder dengan manajer. Manajer beranggapan bahwa ia memiliki kepentingan untuk menggunakan free cash flow dalam investasi yang berkaitan dengan kesempatan bertumbuh diatas ukuran yang optimal dan kompensasi yang akan diterimanya sebagai imbalan dari pertumbuhan tersebut, sedangkan shareholder beranggapan bahwa free cash flow harus dibagikan sebagai deviden. Tuntutan shareholder tersebut muncul karena adanya kecenderungan bahwa para manajer akan berinvestasi pada proyek yang merugikan investor. Dengan demikian manajer beranggapan bahwa tuntutan investor yang berupa pembagian tambahan deviden akan menghalangi pencapaian tujuannya.

Overinvestment problem ini dapat diatasi dengan menggunakan hutang sebagai sumber pendanaan investasi pada proyek-proyek yang baru. Hutang juga digunakan sebagai jaminan (bonding) bahwa free cash flow akan dibayarkan sebagai deviden bagi shareholder, sekaligus akan menempatkan perusahaan dan manajer pada pengawasan pihak eksternal, sehingga kecenderungan manajer untuk berinvestasi pada proyek dengan NPV negatif dapat dicegah.

Perusahaan dengan overinvestment problem pada umumnya memiliki assets in place yang besar. Assets in place yang besar dalam perusahaan dapat digunakan sebagai jaminan pada kebijakan pengambilan hutang, sehingga memungkinkan perusahaan mengambil tingkat hutang 
yang tinggi. Dengan demikian perusahaan dengan overinvestment problem memiliki tingkat hutang yang tinggi. Berbagai tingkat penggunaan hutang akibat adanya underinvestment problem dan overinvestment problem digambarkan oleh Barclay, et.al. (2001) pada tabel 1.

Tabel 1

Tingkat Penggunaan Hutang Berdasarkan Konsep IOS

\begin{tabular}{|l|c|c|}
\hline \multirow{2}{*}{} & \multicolumn{2}{|c|}{ Investment Opportunity Set } \\
\cline { 2 - 3 } & $\begin{array}{c}\text { Growth } \\
\text { Opportunities }\end{array}$ & Asset in Place \\
\hline $\begin{array}{l}\text { Cost of Debt } \\
\text { (Underinvestment) }\end{array}$ & High & Low \\
\hline $\begin{array}{l}\text { Benefit of Debt } \\
\text { (Free Cash Flow) }\end{array}$ & Low & High \\
\hline Optimal Leverage & Low & High \\
\hline
\end{tabular}

Sumber: Barclay, M..J., Marx, L.M., dan Smith, C.W., 2001. The joint determination of leverage and maturity. Working Paper, p: 9.

Selanjutnya Myers (1977) mengatakan bahwa cara mengontrol underinvestment problem selain dengan menggunakan hutang dalam jumlah yang kecil, juga dilakukan dengan memperpendek maturitas hutang. Sejalan dengan Myers (1977), Bodie dan Taggart (1978, dalam Barnea, et.al.,1980) menyatakan bahwa dengan memperpendek maturitas hutang dapat mengatasi problem yang berhubungan dengan investment opportunity dimasa depan. Hal senada juga disampaikan oleh Barnea, et.al. (1980) yang menyatakan bahwa konflik yang terjadi antara shareholder dengan bondholder (underinvestment problem) pada perusahaan dengan investment opportunities yang tinggi, dapat dikontrol dengan memperpendek debt maturity. Dengan memperpendek maturitas hutang maka diharapkan kecenderungan shareholder untuk tidak melaksanakan investasi pada proyekproyek dengan NPV positif dapat dihapuskan.

Sedangkan perusahaan yang memiliki assets in place yang besar (investment opportunity yang rendah), untuk mengontrol overinvestment problem yang dihadapinya sebaiknya perusahaan menggunakan hutang yang besar dengan maturitas hutang yang panjang. Hal ini sejalan dengan hasil penelitian yang dilakukan oleh Stulz (1990, dalam Barclay, et.al., 1995) serta Hart dan Moore (1990, dalam Barclay, et.al., 1995) yang menyatakan bahwa perusahaan dengan assets in place yang besar (investment opportunities yang rendahl) seharusnya mengambil hutang jangka 
panjang, karena hutang jangka panjang akan lebih efektif membatasi kebebasan manajer untuk berinvestasi pada proyek-proyek dengan NPV negatif.

Berbagai penelitian yang dilakukan oleh: Barclay, et.al. (1995), Stohs dan Mauer (1996), dan Guedes, et.al. (1996) menemukan hubungan yang negatif antara investment opportunity set (growth options) dengan debt maturity. Berbagai tingkat debt maturity sebagai akibat adanya underinvestment problem dan overinvestment problem digambarkan oleh Barclay, et.al., (2001) pada tabel 2.

Tabel 2

Tingkat Debt Maturity Berdasarkan Konsep IOS

\begin{tabular}{|l|c|c|}
\hline \multirow{2}{*}{} & \multicolumn{2}{|c|}{ Investment Opportunity Set } \\
\cline { 2 - 3 } & $\begin{array}{c}\text { Growth } \\
\text { Opportunities }\end{array}$ & Asset in Place \\
\hline $\begin{array}{l}\text { Cost of Long Term Debt } \\
\text { (Underinvestment) }\end{array}$ & High & Low \\
\hline $\begin{array}{l}\text { Benefit of Long Term Debt } \\
\text { (Limiting Managerial Discretionari) }\end{array}$ & Low & High \\
\hline Optimal Debt Maturity & Short & Long \\
\hline
\end{tabular}

Sumber: Barclay, M..J., Marx, L.M., dan Smith, C.W., 2001. The joint determination of leverage and maturity. Working Paper, p: 9.

Berdasarkan uraian diatas maka dapat dikembangkan hipotesis sebagai berikut:

$\mathrm{H}_{1 \mathrm{a}}$ : Investment opportunity berpengaruh negatif terhadap leverage

$\mathrm{H}_{1 \mathrm{~b}}$ : Investment opportunity berpengaruh negatif terhadap debt maturity

\section{Firm Size}

Smith dan Warner (1977 dalam Stohs dan Mauer, 1996) menyatakan bahwa perusahaan yang mempunyai investment opportunity yang tinggi pada umumnya merupakan perusahaan yang kecil. Perusahaan tersebut biasanya sedang berusaha untuk tumbuh dengan melaksanakan kesempatan investasi yang dimilikinya dengan menggunakan hutang, sehingga ada kemungkinan terjadi konflik antara shareholder dan bondholder. Myers (1977) menyebut konflik ini sebagai underinvestment problem, yang dapat dikontrol dengan menggunakan hutang dalam jumlah yang kecil serta memperpendek maturitas hutang. Hal ini disebabkan karena perusahaan yang mempunyai intangible assets in place (investment opportunity) yang lebih banyak mempunyai kecenderungan untuk mengalami masalah keuangan. 
Warner (1977) serta Ang, et.al (1982) dalam Titman dan Wessels (1988), Crutchley dan Hansen (1984), serta Rajan dan Zingales (1995) menyatakan bahwa kemungkinan perusahaan yang besar mengalami kebangkrutan adalah kecil, sehingga size berpengaruh positif terhadap tingkat hutang yang diambil.

Sementara itu, Chang dan Rhee (1990) Baskin (1989 dalam Adedeji, 1998), mengatakan bahwa perusahaan yang besar memiliki akses yang lebih baik terhadap pasar kapital hutang, sehingga ukuran perusahaan memiliki pengaruh positif terhadap financial leverage.

Sejalan dengan Myers (1977), Bodie dan Taggart (1978), serta Barnea, et.al. (1980) menyatakan bahwa underinvestment problem dapat dikontrol dengan menurunkan debt maturity. Sedangkan overinvestment problem yang pada umumnya terjadi pada perusahaan dapat dikontrol dengan menggunakan hutang jangka panjang.

Penelitian Bevan dan Danbolt (2000), Chittenden, et.al. (1996) serta Michaelas, et.al. (1999) menemukan pengaruh positif firm size terhadap debt maturity. Dengan demikian small firm diharapkan untuk menggunakan sedikit hutang jangka panjang dibanding larger firm.

Berdasarkan uraian diatas maka dapat dikembangkan hipotesis sebagai berikut:

$\mathrm{H}_{2 \mathrm{a}}$ : Firm size berpengaruh positif terhadap leverage

$\mathrm{H}_{2 \mathrm{~b}}$ : Firm size berpengaruh positif terhadap debt maturity

\section{Efek Signaling}

Megginson (1997) menyatakan bahwa dalam pengambilan keputusan corporate financial oleh manajer seringkali berhubungan dengan efek signaling. Teori signaling telah dibangun dalam literatur ekonomi dan financial yang secara eksplisit memperhitungkan asymmetric information antara corporate insiders (officers dan directors) dengan outsider investors. Dimana corporate insiders secara umum memiliki informasi yang lebih baik tentang modal saat ini dan prospek perusahaan dimasa depan dibanding outsider investors. Dimana asymmetric information akan tercermin dengan adanya reaksi pasar saat perusahaan mengumumkan perubahan struktur modal, yang ditunjukkan dengan perubahan harga saham.

Pengumuman penggunaan hutang yang lebih banyak dalam capital structure perusahaan menunjukkan adanya optimisme pihak insiders mengenai prospek dimasa depan perusahaan, dimana perusahaan akan lebih profitable dan dapat memenuhi kewajiban financial yang harus dipenuhinya. Ross (1977 dalam Megginson, 1997) berpendapat bahwa penggunaan hutang dalam capital structure menunjukkan bahwa insiders dari perusahaan yang profitable memberikan signal tentang perusahaannya yang relatif tidak mudah mengalami kebangkrutan dan bentuk lain dari fi- 
nancial distress, dibanding perusahaan yang kurang profitable. Optimisme perusahaan akan prospek yang lebih baik dimasa depan ini akan ditunjukkan dengan peningkatan harga saham.

Penelitian yang telah dilakukan oleh: Smith (1986), serta Hull dan Moellenberndt (1994) menunjukkan adanya pengaruh yang negatif penerbitan saham sebagai pengganti hutang, terhadap harga saham dan return saham.

Selain itu, setiap pemilihan struktur maturitas yang ditetapkan oleh manajer akan membawa informasi bagi investor. Hal ini sejalan dengan pendapat Flannery (1986 dalam Stohs, et.al., 1996) yang menyatakan bahwa pemilihan struktur umur hutang dapat mengisyaratkan informasi dari pihak insiders tentang kualitas perusahaan ketika pihak insiders memiliki informasi yang lebih baik dibanding outside investors. Dimana, menurut Flannery (1986 dalam Stohs, et.al., 1996) perusahaan yang kuat akan menunjukkan tipenya dengan memilih untuk mengeluarkan hutang jangka pendek dibanding perusahaan yang lebih lemah. Hal ini dikarenakan pengambilan hutang jangka pendek akan mendorong perusahaan untuk mengambil resiko untuk mendanai kembali hutang (rolling over) setelah informasi tambahan perusahaan diungkapkan. Sedangkan perusahaan dengan prospek yang kurang menjanjikan cenderung tidak bersedia untuk mengambil resiko tersebut, sehingga akan lebih memilih hutang jangka panjang.

Diamond (1991) menyatakan bahwa pemilihan maturitas hutang sebagai trade-off antara preferensi peminjam untuk menerbitkan hutang jangka pendek karena memiliki informasi pribadi tentang rengking kredit dimasa depan, dan resiko likuidasi. Menurut Diamond (1991), perusahaan yang memiliki rengking yang tinggi akan menerbitkan hutang jangka pendek dan perusahaan dengan rengking kredit rendah akan menerbitkan hutang jangka panjang.

Sementara itu Diamond (1993 dalam Megginson, 1997) menyatakan bahwa penggunaan hutang jangka pendek disisi lain akan meningkatkan resiko likuiditas bagi para manajer perusahaan, dan juga meningkatkan sensitifitas biaya pendanaan atas informasi baru. Perusahaan yang kuat akan memprediksikan nilai earning per share (EPS) yang meningkat (high quality firm), sehingga perusahaan seperti ini akan memilih hutang jangka pendek. Hal ini sejalan dengan Barclay dan Smith (1995) yang menyatakan bahwa menurut teori signaling perusahaan yang undervalued (high quality firm) akan memiliki leverage yang lebih tinggi, dan hutang jangka pendek yang lebih banyak, dibanding perusahaan yang overvalued (low quality firm).

$\mathrm{H}_{3 \mathrm{a}}$ : Efek signaling berpengaruh positif terhadap leverage

$\mathrm{H}_{3 \mathrm{~b}}$ : Efek signaling berpengaruh negatif terhadap debt maturity 


\section{Non-Debt Tax Shield}

Modigliani dan Miller (1963) menyatakan bahwa bunga hutang dapat digunakan sebagai alat untuk mengurangi pajak penghasilan (interest tax shield) yang harus dibayar oleh perusahaan. Selanjutnya Modigliani et.al (1963) berpendapat bahwa adanya interest tax shield menyebabkan perusahaan cenderung menggunakan hutang dalam jumlah yang tinggi.

Berkaitan dengan tax shield, De Angelo et. al. (1980) menyatakan bahwa potongan pajak (tax deduction) yang berupa depresiasi dan investment tax credit dapat digunakan untuk mengurangi pajak selain bunga hutang. Akibatnya perusahaan dengan non debt-tax shield yang tinggi akan menggunakan hutang yang kecil dalam struktur modalnya.

Sementara penelitian yang dilakukan oleh McKie-Mason (1990), yang sejalan dengan pendapat De Angelo, et.al. (1980), membuktikan adanya pengaruh negatif antara non-debt tax shield dengan penggunaaan hutang. Keadaan ini menurut McKie-Mason (1990) dikarenakan adanya kecenderungan bahwa kerugian yang dialami oleh perusahaan dijadikan alasan untuk membebaskan perusahaan dari kewajiban membayar pajak pada tahun berikutnya (tax loss carryforward). Untuk itu zero tax status diberikan pada perusahaan. Maka perusahaan akan menggunakan hutang dalam jumlah yang kecil, karena tanpa bunga hutang perusahaan terbebas dari kewajiban membayar pajak.

Berdasarkan pendapat DeAngelo (1980) dan McKie-Mason (1990), maka dapat dikembangkan hipotesis sebagai berikut:

$\mathrm{H}_{4}$ : $\quad$ Non-debt tax shield berpengaruh negatif terhadap leverage

\section{Asset Maturity}

Barnea, et. al. (1980) menyatakan bahwa penentuan maturitas dari outstanding debt merupakan kebijakan perusahaan yang penting, yang mempengaruhi distribusi kesejahteraan sejumlah pemegang sekuritas perusahaan.

Teori financial menjelaskan bahwa struktur maturitas hutang menunjukkan bahwa debt maturity yang optimal tercapai pada saat maturitas hutang dan maturitas asset adalah sama untuk meminimalisasi ketidakpastian dari fluktuasi interest rate (Modigliani dan Sutch, 1966 dalam Barnea et.al.,1980). Sejalan dengan hal tersebut Brigham et.al. (1999) serta Stohs dan Mauer (1996) menyatakan bahwa perusahaan harus menyesuaikan kebijakan maturitas hutang dengan maturitas asset yang dimilikinya. Jika hutang memiliki tingkat maturitas yang lebih panjang dari maturitas assetnya, maka ada kecenderungan perusahaan tidak memiliki kas yang cukup untuk membayar hutang pada saat jatuh tempo. Sebaliknya jika hutang memiliki tingkat maturitas yang lebih pendek dari maturitas assetnya, maka perusahaan akan kekurangan dana untuk mendanai kem- 
bali hal-hal penting yang harus didanai. Argumen ini didukung oleh Myers (1977, dalam Megginson, 1997) yang memberikan pembenaran teoritis atas praktek-praktek umum dari penyesuaian atas umur aktiva (asset maturity) perusahaan dengan hutang yang dikeluarkan untuk mendanainya, karena hal ini memungkinkan dilakukannya pembayaran kembali sesuai dengan penurunan nilai aktiva tersebut dimasa yang akan datang (matching hypotheses).

Berdasarkan uraian diatas maka dapat dikembangkan hipotesis sebagai berikut:

$\mathrm{H}_{2 \mathrm{~d}}$ : Asset Maturity berpengaruh positif terhadap debt maturity

\section{METODE PENELITIAN}

\section{Data dan Sampel}

Penelitian ini mengambil data yang terdiri dari perusahaanperusahaan manufaktur yang terdaftar di Bursa Efek Jakarta dari tahun 1994 sampai dengan 1998. Pemilihan periode waktu tersebut didasarkan atas pertimbangan dari penggunaan variabel fasilitas perpajakan (non-debt tax shield), yang mulai aktif diberlakukan di Indonesia pada tahun 1994. Dengan menggunakan metode purposive sampling, maka hanya sampel yang memenuhi kriteria tertentu saja yang diambil sebagai sampel penelitian. Adapun kriteria-kriteria yang digunakan dalam pengambilan sampel adalah sebagai berikut: (1) perusahaan yang diteliti adalah perusahaan manufaktur yang go public dan terdaftar di Bursa Efek Jakarta selama periode penelitian, (2) perusahaan tersebut harus tetap ada selama periode penelitian, yaitu dari tahun 1994 sampai 1998, dan (3) perusahaan tersebut memiliki laporan keuangan serta mempunyai laporan hutang jangka panjang dan hutang jangka pendek secara kontinyu selama periode penelitian. Pengambilan data dilakukan melalui sumber sekunder, yaitu Indonesia Capital Market Directory, data tentang fasilitas perpajakan dari Direktorat Jenderal Pajak Pusat, dan Database pasar modal UGM. Berdasarkan kriteria tersebut terpilih 130 perusahaan sampel.

\section{Metode Analisis Data}

Untuk menguji hipotesis yang telah dikembangkan maka digunakan model persamaan two-stage least square (2SLS) dengan bantuan program SPSS versi 10.0. Penggunaan metode analisis two-stage least square (2SLS) pada penelitian ini disebabkan karena model persamaan yang digunakan mempunyai hubungan sebab akibat lebih dari satu arah. Dalam model persamaan ditemukan bahwa variabel dependen $(Y)$ tidak hanya ditentukan oleh variabel dependen $(X)$ saja, tetapi beberapa variabel dependen (X) juga ditentukan oleh variabel dependen (Y) (Gujarati, 1999). 
Dimana kondisi tersebut menunjukkan terdapat hubungan simultanitas antara variabel $X$ dan $Y$. Dalam hubungan simultanitas, biasanya terdapat lebih dari satu persamaan dan penaksiran tidak dapat dilakukan secara terpisah tanpa memperhitungkan informasi yang diberikan oleh persamaan yang lain (Gujarati, 1999). Oleh karena ada dugaan dalam penelitian ini, bahwa kebijakan hutang dipengaruhi oleh kebijakan maturitas hutang, dan kebijakan maturitas hutang dipengaruhi oleh kebijakan hutang, maka metode analisis simultan 2SLS diterapkan. Karena, menurut Gujarati (1999) dalam persamaan yang mengandung hubungan simultanitas seandainya dianalisis dengan menggunakan regresi biasa (ordinary least square) akan sangat berpotensi mengasilkan taksiran yang bias dan tidak konsisten. Hal ini dikarenakan, bahwa dalam persamaan simultan sangat besar kemungkinan variabel endogen berkorelasi dengan error term. Untuk itu, menurut Gujarati (1999) akan lebih tepat bila penelitian ini menggunakan metode 2SLS, karena dalam analisis ini semua variabel diperhitunkan sebagai suatu sistem secara menyeluruh. Secara matematis persamaan leverage dan persamaan debt maturity dirumuskan sebagai berikut:

$$
\begin{gathered}
\text { Leverage }=\alpha_{10}+\alpha_{11} D M+\alpha_{12} M T B E Q+\alpha_{13} L S+\alpha_{14} F A E+\alpha_{15} N D T S+\varepsilon_{1} \\
\text { Debt Maturity = } \\
\alpha_{20}+\alpha_{21} L E V E R A G E+\alpha_{22} M T B E Q+\alpha_{23} L S+\alpha_{24} F A E+ \\
\alpha_{25} A S M A T+\varepsilon_{2}
\end{gathered}
$$

Keterangan proksi:

$$
\begin{array}{ll}
\text { DM } & : \text { debt maturity } \\
\text { LS } & : \text { firm size } \\
\text { MTBEQ } & : \text { market to book value of equity (IOS) } \\
\text { ASMAT } & : \text { assets maturity } \\
\text { FAE } & : \text { future abnormal earning (efek signaling) } \\
\text { NDTS } & : \text { non-debt tax shield }
\end{array}
$$

Untuk melakukan analisis dengan metode 2SLS, sebelum memasuki tahap analisis 2SLS, setiap persamaan harus memenuhi persyaratan identifikasi. Suatu persamaan dikatakan identified hanya jika persamaan tersebut dinyatakan dalam bentuk statistik unik, dan menghasilkan taksiran parameter yang unik (Sumodiningrat, 2001). Menurut Gujarati (1999) untuk memenuhi syarat tersebut maka suatu variabel pada persamaan satu harus tidak konsisten pada persamaan yang lain. Identifikasi persamaan dapat dilakukan dengan memasukkan atau menambah, atau mengeluarkan beberapa variabel eksogen (atau endogen) kedalam persamaan (Sumodiningrat, 2001). Identifikasi ini dimaksudkan untuk menentukan apakah persamaan tersebut ada pada kondisi sebagai under identification (tidak bisa teridentifikasi), exact identification (tepat teridentifikasi), atau kondisi over idetification (terlalu teridentifikasi). 
Ketiga kondisi tersebut dapat ditentukan dengan menggunakan rumus sebagai berikut:

$\mathrm{K}-\mathrm{k}<\mathrm{m}-1$ : disebut sebagai under idefidentification

$\mathrm{K}-\mathrm{k}=\mathrm{m}-1:$ disebut exact identification

$\mathrm{K}-\mathrm{k}>\mathrm{m}-1$ : disebut over idetification,

dimana,

$\mathrm{K} \quad$ : jumlah variabel eksogen predetermined dalam model

k $\quad$ : jumlah variabel eksogen predetermined dalam persamaan

m : jumlah variabel endogen dalam persamaan

Berdasarkan kreteria tersebut maka identifikasi persamaan dalam model penelitian ini adalah sebagai berikut:

Tabel 3

Indentifikasi Persamaan Model Simultan

\begin{tabular}{|l|l|l|l|l|}
\hline \multicolumn{1}{|c|}{ Persamaan } & $\mathrm{K}$ & $\mathrm{k}$ & $\mathrm{m}$ & \multicolumn{1}{c|}{ Identifikasi } \\
\hline Leverage & 5 & 4 & 2 & Exactly identified \\
Debt Maturity & 5 & 4 & 2 & Exactly identified \\
\hline
\end{tabular}

Hasil identifikasi persamaan leverage dan debt maturity menunjukkan bahwa masing-masing persamaan adalah exactly identified. Keadaan tersebut memenuhi pesyaratan identifikasi persamaan 2SLS.

\section{Penjelasan Variabel Leverage}

Besarnya leverage atau tingkat penggunaan hutang dihitung dengan menggunakan pendekatan nilai pasar hutang (market leverage ratio), yaitu perbandingan antara nilai buku total hutang dengan nilai pasar perusahaan (Barclay, et.al. 1995). Rasio ini digunakan dengan pertimbangan karena adanya kecenderungan penggunaan hutang yang pada umumnya didasarkan pada besarnya aktiva yang dapat dijadikan jaminan (collateralizable assets). Market leverage ratio dirumuskan sebagai berikut:

$$
\text { Leverage }=\frac{\text { book value of total debt }}{\text { market value of the firm }}
$$

Dimana nilai pasar perusahaan dihitung dengan rumus sebagai berikut:

$$
\text { Market value of the firm }=\text { total debt }+\left[\left(\frac{E A T}{E P S}\right) \times \text { closing price }\right]
$$

\section{Debt maturity}

Proksi yang digunakan untuk mengukur debt maturity adalah rasio dari long-term debt to total debt. Hal ini didasarkan pada penelitian Barclay, et.al. (1995) dan Barclay, et. al. (2001), dimana proksi ini mampu mencerminkan proporsi hutang jangka panjang dan hutang jangka pendek. Rasio ini dirumuskan sebagai berikut: 


\section{Debt maturity $=\frac{\text { Hutang jangka panjang }}{\text { Total hutang }} \times 100 \%$ \\ Investment Opportunity}

Besarnya investment opportunity yang dimiliki oleh perusahaan menunjukkan potensi tingkat pertumbuhan dimasa depan, sehingga investment opportunity akan diukur dengan pertumbuhan dimasa depan. Barclay, et. al. (1995) mengatakan bahwa market-to-book value mampu mencerminkan potensi nilai perusahaan di masa depan. Dengan demikian penelitian ini akan menggunakan market-to-book value of equity sebagai proksi dari IOS (Gaver dan Gaver, 1993). Adapun market-to-book value of equity dapat dirumuskan sebagai berikut:

$$
\text { Market }- \text { to - book value of equity }=\frac{\left(\frac{E A T}{E P S}\right) \times \text { closing price }}{\text { common equity }}
$$

\section{Firm Size}

Untuk menentukan ukuran perusahaan digunakan natural logarithm of sales. Ben-Zion dan Shalit (1975) menyatakan bahwa sales lebih menujukan ukuran langsung dari size. Dan menurut Johnson (1997) yang dikutip oleh Nursanti (2001), sales dijadikan sebagai indikator ukuran perusahaan karena sifat alamiah bisnis (the nature of business) menunjukkan bahwa total assets yang tinggi tidak selalu mencerminkan tingkat profitabilitas yang tinggi.

\section{Efek Signaling}

Barclay et.al. (1995) berpendapat bahwa alat prediksi yang tepat untuk mengukur kualitas perusahaan adalah dengan melihat kecenderungan perubahan earning dimasa depan. Perusahaan dikatakan berkualitas tinggi (high quality) bila memiliki kenaikan earning pada tahun berikutnya, dan sebaliknya untuk perusahaan yang low quality. Barclay et.al. (2001) menggunakan future abnormal earning untuk mengukur efek signaling yang menunjukkan kualitas perusahaan. Future abnormal earning dihitung dengan rumus sebagai berikut:

\section{Non-Debt Tax Shield}

$$
\text { Future abnormal earning }=\frac{E P S_{t+1}-E P S_{t}}{\text { closing price } t_{t}}
$$

Non-debt tax shield diukur dengan menggunakan dummy variable, yaitu angka 1 untuk perusahaan yang memperoleh fasilitas pajak dari pemerintah, dan angka 0 untuk perusahaan yang tidak memperoleh fasilitas pajak. Fasilitas pajak dari pemerintah tersebut berupa keringanan yang didasarkan atas lokasi maupun berdasarkan jenis industri. 


\section{Asset Maturity}

Asset maturity dapat diukur dengan rumus sebagai berikut (Stohs dan Mauer, 1996):

Assets maturity $=1 / 2\left(\frac{\text { Total aktiva lancar }}{\text { Harga pokok penjualan }}+\frac{\text { Total aktiva tetap }}{\text { Depresiasi }}\right) \times 100 \%$

\section{HASIL ANALISIS DAN PEMBAHASAN}

\section{Tabel 4}

Hasil Regresi 2SLS

\begin{tabular}{|l|r|r|}
\hline \multicolumn{3}{|c|}{ Two-stage least square regresions } \\
\hline Intersept & \multicolumn{1}{|c|}{ Leverage } & Debt Maturity \\
\hline Leverage & 3.5089 & -1.8230 \\
& $(9.537)^{\star \star \star}$ & $(-10.382)^{\star \star \star}$ \\
\hline Debt maturity & & 2.9341 \\
& & $(11.824)^{\star \star \star}$ \\
\hline Market-to-book value of equity & 2.9898 & \\
& $(10.108)^{\star \star \star}$ & -0.0010 \\
\hline Firm size & -0.0018 & $(-0.664)$ \\
& $(-0.933)$ & 0.0642 \\
\hline Efek signaling & -0.7135 & $(1.935)^{\star}$ \\
\hline Non debt tax shield & $(-8.598)^{\star \star \star}$ & -0.0337 \\
& 0.0100 & $(-3.372)^{\star \star \star}$ \\
\hline Asset maturity & $(0.880)$ & 0.0062 \\
& 0.1156 & $3.476 * \star$ \\
\hline R Square & $(3.113)^{\star \star \star}$ & 0.65454 \\
\hline
\end{tabular}

Keterangan:

*** = signifikan pada level $1 \%$

** = signifikan pada level $5 \%$

* $\quad$ = signifikan pada lefel $10 \%$

Dari hasil analisis persamaan leverage dan debt maturity, dapat diketahui bahwa koefisien debt maturity maupun leverage adalah positif dan signifikan. Ini menunjukkan bahwa hubungan antara kebijakan leverage dan debt maturity adalah komplementer, yang berarti ada arah hubungan simultanitas yang positif antara kedua kebijakan tersebut. Dengan demikian penelitian ini mendukung hasil penelitian Barclay, et.al. (2001), dan Stohs dan Mauer (1996), serta konsisten dengan hipotesis bahwa perusahaan 
memperpanjang maturitas hutang sejalan dengan peningkatan leverage untuk menghindari krisis likuiditas.

Investment opportunity diukur dengan tingkat pertumbuhan, yaitu market to book value of equiy, menunjukkan pengaruh yang negatif dan tidak signifikan baik pada kebijakan leverage maupun debt maturity. Pengaruh negatif investment opportunity terhadap leverage maupun debt maturity tidak konsisten dengan hipotesis yang diajukan. Tidak signifikannya nilai koeefisien market to book value of equiy disebabkan karena ada kemungkinan bahwa market to book value of equiy tidak mencerminkan tingkat pertumbuhan perusahaan di Indonesia. Dengan demikian pemilihan market to book value of equiy sebagai proksi tingkat pertumbuhan pada penelitian ini tidak tepat.

Firm size yang diukur dengan logsale, menunjukkan pengaruh yang negatif dan signifikan terhadap kebijakan leverage. Pengaruh negatif antara firm size dengan leverage tidak konsisten dengan hipotesis yang diajukan. Tetapi hasil penelitian ini konsisten dengan Smitt (1977), Barclay, Smith, dan Watts (1995) dan Barclay et.al. (2001). Argumen yang bisa dikemukakan disini adalah large firm akan memiliki free cash flow yang tinggi, sehingga bila memerlukan tambahan dana untuk membiayai investasi baru, maka perusahaan tersebut akan menggunakan sumber pendanaan yang murah yaitu sumber pendanaan dari dalam yang berupa retained earning. Seandainya sumber pendanaan dari dalam perusahaan tidak mencukupi, perusahaan akan beralih pada sumber pendanaan dari luar yang berasal dari hutang daripada penerbitan saham baru. Sedangkan pada perusahaan yang kecil (small firm) akan memiliki free cash flow yang rendah, sehingga sumber pendanaan dari dalam tidak bisa mencukupi tambahan dana investasi yang diperlukan, untuk itu perusahaan akan menerbitkan hutang daripada saham baru. Hal ini dikarenakan biaya emisi saham lebih besar daripada biaya emisi hutang (Brigham, Gapenski, dan Daves, 1999). Dan, menurut Smitt (1977, dalam Titman dan Wessels, 1988) flotation cost untuk penerbitan new equity pada perusahaan yang kecil akan lebih mahal daripada perusahaan yang besar. Berdasarkan hal tersebut perusahaan yang kecil cenderung akan memilih hutang untuk membiayai investasinya, terutama yang berupa hutang bank. Sedangkan pada kebijakan debt maturity dapat dilihat bahwa firm size berpengaruh positif dan signifikan. Pengaruh positif firm size ini, sesuai dengan hipotesis yang diajukan, serta hasil yang dilakukan oleh Titman dan Wessels (1988), Bevan dan Danbolt (2000), dan Barclay dan Smith (1995).

Efek signaling yang diukur dengan future abnormal earning, menunjukkan pengaruh yang positif dan tidak signifikan terhadap kebijakan leverage. Pengaruh yang positif dan tidak signifikan efek signaling terhadap kebijakan leverage tidak konsisten dengan hipotesis yang diajukkan. Tidak 
signifikannya nilai koeefisien future abnormal earning menunjukkan bahwa leverage tidak dapat dipakai sebagai indikasi tingkat profitabilitas perusahaan di Indonesia. Sebab tingkat profitabilitas di Indonesia biasanya diindikasikan melalui tingkat pembayaran dividen dan harga saham. Dengan demikian hasil penelitiaan ini tidak mendukung teori signaling. Sedangkan pada kebijakan debt maturity dapat dilihat bahwa efek signaling menunjukkan pengaruh yang negatif dan signifikan. Hasil penelitian ini konsisten dengan penelitian Barclay dan Smith (1995) yang membuktikan bahwa perusahaan yang berkualitas tinggi akan menggunakan lebih banyak hutang jangka pendek, dan memberikan dukungan terhadap teori signaling.

Dari hasil analisis dapat dilihat bahwa non-debt tax sield berpengaruh positif dan signifikan terhadap kebijakan leverage. Pengaruh positif non-debt tax sield terhadap leverage tidak konsisten dengan hipotesis yang diajukan. Tetapi hasil penelitian ini konsisten dengan hasil penelitian Scott (1976), Chang dan Rhee (1990), dan Barclay et.al (2001). Argumen yang bisa dikemukakan disini adalah investment tax credit sebagai proksi untuk non-debt tax shield pada umumnya diberikan kepada perusahaanperusahaan yang memiliki tangible asset yang besar, contohnya KMK No. 19/KMK. 04/1994, diikuti SE-31/PJ. 52/Juli 1995, SE-58/PJ. 52/Desember 1995, dan SE-72/PJ. 52/April 1996, tentang fasilitas PPN ditanggung pemerintah bagi impor emas batangan dan pabrik emas batangan pada industri emas, sehingga bisa digunakan untuk collateral bagi pengambilan hutang. Hal ini sesuai dengan pendapat Scott (1976, dalam Noronha, Shome, dan Morgan, 1996) yang menyatakan bahwa pada perusahaan dengan depresiasi dan tingkat investment tax credit yang besar sebagai proxy untuk non-debt tax shield, menunjukkan bahwa perusahaan tersebut memiliki tangible asset yang besar sehingga bisa digunakan untuk collateral bagi pengambilan hutang, dengan demikian non-debt tax shield berhubungan positif dengan leverage.

Dari hasil analisis dapat dilihat bahwa asset maturity berpengaruh positif dan signifikan terhadap debt maturity. Pengaruh positif asset maturity terhadap debt maturity konsisten dengan hipotesis yang diajukan, dan hasil penelitian Stohs dan Mauer (1996), serta memberikan dukungan bagi matching hypothesis.

SIMPULAN

Penelitian ini menguji simultanitas kebijakan hutang dan kebijakan debt maturity serta factor-faktor yang mempengaruhinya dengan analisis simultanitas 2SLS, dengan tiga variabel eksogen yang mempengaruhi simultanitas kebijakan hutang dan kebijakan debt maturity, serta dua variabel tambahan sebagai syarat identifikasi persamaan simultan 2SLS. Dari 
hasil pengujian kedua kebijakan tersebut secara simultan, menunjukkan hasil bahwa kebijakan hutang dan kebijakan maturitas hutang mempunyai hubungan yang komplementer, yang berarti bahwa ada arah hubungan simultanitas yang positif antara kebijakan hutang dan maturitas hutang.

Pada pengujian secara bersama-sama variabel-variabel eksogen menunjukkan pengaruh yang signifikan terhadap kebijakan hutang dan kebijakan maturitas hutang. Pada persamaan leverage pengaruh variabel eksogen secara bersama-sama ditunjukkan dengan nilai $R$ squared sebesar $46.944 \%$, dan pada persamaan debt maturity pengaruh variabel eksogen secara bersama-sama ditunjukkan dengan nilai $R$ squared sebesar $65.454 \%$.

Dimana dari hasil pengujian, variabel eksogen yang terbukti memiliki pengaruh yang signifikan terhadap kebijakan hutang adalah firm size dan non-debt tax shield, tetapi tidak menunjukkan pengaruh yang konsisten dengan hipotesis yang diajukan. Sedangkan variabel investment opportunity dan efek signaling menunjukkan pengaruh yang konsisten dengan hipotesis tetapi tidak signifikan.

Sementara itu, variabel eksogen yang terbukti memiliki pengaruh yang signifikan terhadap kebijakan maturitas hutang adalah firm size, efek signaling dan asset maturity. Yang berarti hasil penelitian ini mendukung signaling hypothesis dan matching hypothesis. Sedangkan variabel investment opportunity menunjukkan pengaruh yang konsisten dengan hipotesis tetapi tidak signifikan.

\section{KETERBATASAN DAN IMPLIKASI}

Penelitian ini tidak dapat terlepas dari berbagai keterbatasan. Pertama Perusahaan yang diambil sebagai sampel adalah perusahaan manufaktur yang terdaftar di BEJ, berarti bahwa simultanitas antara kebijakan hutang dan kebijakan maturitas terbatas hanya pada perusahaan manufaktur, belum mencerminkan simultanitas antara kebijakan hutang dan kebijakan maturitas untuk seluruh perusahaan. Hasil yang lebih baik mungkin dapat diperoleh seandainya penelitian menggunakan sampel seluruh perusahaan yang ada di BEJ. Untuk itu, disarankan untuk penelitian berikutnya menggunakan sampel seluruh perusahaan yang ada di BEJ. Keterbatasan yang kedua adalah hasil yang tidak konsisten pada variabel logsales sebagai proksi firm size, dan penggunaan dummy variable bagi perusahaan penerima fasilitas pajak sebagai proksi untuk non-debt tax sield, dengan hipotesis pada persamaan leverage, serta market to book value of equity sebagai proksi tingkat pertumbuhan, dengan hipotesis pada persamaan leverage maupun debt maturity, maka penelitian berikutnya dapat menggunakan proksi yang lain, yang dapat memberikan hasil yang 
lebih baik. Keterbatasan yang ketiga adalah penelitian ini hanya terfokus pada kebijakan leverage dan debt maturity, dan mengeluarkan variabel kebijakan yang lain, seperti kebijakan dividen. Dimana peniadaan hubungan variable kebijakan dividen ini dapat membiaskan estimasi koefisien. Dengan adanya dugaan bahwa kebijakan dividen mempengaruhi simultanitas kebijakan hutang dan kebijakan maturitas hutang, maka penelitian selanjutnya dapat memasukkan variable kebijakan dividen dalam penelitian. Keterbatasan yang keempat adalah penelitian ini tidak melakukan pembagian periode sebelum dan sesudah krisis, untuk itu pengujian selanjutnya bisa dilakukan dengan membandingkan periode pengamatan sebelum dan sesudah krisis. Tujuannya adalah untuk mengetahui bagaimana hubungan antara kebijakan hutang dan kebijakan maturitas hutang pada analisis simultanitas kebijakan hutang dan maturitas hutang sebelum dan sesudah krisis, apakah ada perbedaan atau tidak. Selain itu penelitian ini tidak menutup kemungkinan untuk memasukkan variabel eksogen lain, yang diangggap mempunyai pengaruh yang signifikan terhadap kedua kebijakan tersebut.

\section{DAFTAR PUSTAKA}

Adedeji, A. 1998. Does The Pecking Order Hypothesis Explain The Dividend Payout Ratio Of Firms InThe UK? Journal of Business Finance \& Accounting, November/ December: 1127-1155

Barclay, M.J., dan Smith, C.W. 1995. The maturity structure of corporate debt, The Journal of Finance, Vol.L.No.2, June: 609-631.

Barclay, M.J., dan Smith, C.W. 1995. On financial architecture: leverage, maturity, and priority. The New Corporate Finance: Where Theory Meets Practice, International Edition. Irwin McGraw-Hill: 230-243.

Barclay, M.J., dan Smith, C.W., Watts, R.S. 1995. The Determinand of corporate leverage and dividend policies. The New Corporate Finance: Where Theory Meets Practice, International Edition. Irwin McGraw-Hill: 214-229.

Barclay, M.J., Marx, L.M., dan Smith, C.W. 2001. The joint determinant of leverage and maturity, Working Paper: 2-27.

Barnea, A., Hougen, R.A., dan Senbet, L.M. 1980. A rationale for debt maturity structure and call provisions in the agency theoretic framework, The Journal of Finance, Vol. XXXV, No. 5, December: 12231234. 
Ben-Zion, U., dan Shalit, S.S. 1975. Size, leverage, and divident record as determinants of equity risk, The Journal of Finance, Vol. XXX, No. 4. September: 1015-1026.

Bevan, A.A. dan Danbolt, J. 2000. Dynamics in the determinants of capital structure in the United Kingdom, Paper, Preseted at the Ace project workshop financial flows and debt structure in transition and market economics, Bulgaria, Hungaria, and the United Kingdom, Budapest: 1-37.

Bradley, M.J., Jarrel, G.A. Dankim, H. 1984, On the existence of an optimal capital structure: Theory and Evidence, Journal of Finance, July, 39 (3): 857-878.

Brigham, E.F., Gapenski, L.C., dan Daves, P.R. 1999. Intermediate Financial Management, Sixth Edition.The Dryden Press, Harcourt Brace College Publishers.

Chung, R.P., dan Rhee, S.G. 1990. The impact of personal taxes on corporate, dividend policy and capital structure decitions, Financial Management, Summer: 21-31.

Cooper, D.R., dan Rhee, S.G., 1999. Metode Penelitian Bisnis, Edisi 5. Penerbit Erlangga.

Crutchley, C. E., dan Hansen, R.S. 1989. A test of agency theory of managerial ownership, corporate leverage, and corporate divident. Financial Management, Winter: 36-46.

DeAngelo, H., dan Masulis, R.W. 1980. Optimal capital structureunder corporate nd personal taxition. Journal of Financial Economics, 8:3-29.

Diamond, D.W., 1991. Debt maturity structure and liquidity risk. Quarterly Journal of Economics, 106: 709-737.

Gaver, J.J, dan Gaver, K.M. 1993. Additional evidence on the assosiation between the investment opportunity set and corporate financing, devidend, and compensation policies. Journal of Accounting and Economics, 16: 125-160.

Guedes, J., dan Opler, T. 1996. The Determinants of the Maturity of Corporate Debt Issues, The Journal of Finance, Vol. LI, No. 1, December: 1809-1833.

Gujarati, D. 1999. Ekonometrika Dasar. Penerbit Erlangga. 
Hull, R.M., dan Moellenberndt, R. 1994. Bank Debt Reduction Announcements and Negatif Signaling, Financial Management, Vol. 23, No. 2, Summer: 21-30.

Jensen, M.C. 1986. Agency cost of free cash flow, corporate finance, and takeovers. American Economic Review, May, 76 (2): 323-329.

Long, M., dan Malitz, I. 1995. The investment-financing nexus: Some empirical evidence. The Revolution in Corporate Finance, Second Edition. Basil Blackwell Inc.: 156-162.

McKie-Mason, J.K. 1990. Do taxes affect corporate financing decition? Journalof Finance, December, 55 (5): 1471-1493.

Megginson, W.L., 1997. Corporate Finance Theory. Addison Wesley Educational Publishers.

Modigliani, F., dan Miller, M.H., 1963. Corporate income taxes and the lost of capital: A correction. American Economics Review, June: 433-443.

Myers, S.C. 1977. Determinant of corporate borrowing. Journal of Financial Economics, 5: 147-175.

Noronha, G.M., Shome, D.K., dan Morgan, G.E. 1996. The monitoring rationale for dividends and the interaction of capital structure and divident decision. Journal of Banking and Finance, 20: 439-454.

Rajan, G.R., dan Zingales, L. 1995. What do we know about capital structure? Some evident from international data, Journal of Finance, Des: $14121-14160$

Smith, C. 1986. Investment banking and the capital acquisition process. Journal of Financial Economics, 15: 3-29.

Stohs, M.H., dan Mauer,D.c. 1996. The determinant of corporate debt maturity structure, Journal of Business, 69 (3): 117-161.

Sumodiningrat, G. 2001. Ekonometrika Pengantar. BPFE Yogyakarta.

Titman, Sheridan, dan Roberto Wessels. 1988. The determinant of capital structure choice, Journal of Finance, March 43 (1):1-19.

Widawati, I.A.P., 2001, Analisis Pemilihan Struktur Umur Hutang (Studi Empiris Di Bursa Efek Jakarta), Tesis Pasca sarjana UGM. 